\title{
The Impact of Service Employees and Servicescape on Customers' Perception of Quality Improvement Efforts
}

\author{
By Nha Nguyen ${ }^{*} \&$ Gaston LeBlanc ${ }^{ \pm}$
}

\begin{abstract}
The present study contributes to the understanding of the influence of service employees and the tangible components of the service production and delivery system on perceptions of quality improvement efforts in a service organization. A hierarchical multiple regression with interaction analysis was performed on data collected from a convenience sample of 435 respondents in a higher education institution to assess the main effect of service employees and servicescape, as well as their interactive effect, on customers' perception of the institution's quality improvement efforts. The results show a significant effect of service employees, servicescape as well as the interaction between service employees and servicescape in their influence on customers' perception of quality improvement efforts. The results also reveal that the servicescape intervenes as a moderator variable in the relationship between service employees and quality improvement efforts. Service organizations should therefore focus on the crucial role of service employees during the service encounter and recognize the importance of the servicescape, in view of increasing customers' favourable perceptions towards the service organisation's capability to provide better quality in order to satisfy their needs. The study has limited generalization given the convenience sample and the great variety of service industries. It would be helpful to realize similar studies in other service settings and to explore the exact nature of the interaction between service employees and servicescape.
\end{abstract}

Keywords: Service employees, servicescape, quality improvement efforts

\section{Introduction}

For all business organizations concerned with meeting customers' needs and expectations, quality improvement remains one of its strategic objectives (Buzzel and Weirsema 1981, Jiju 2015, Kettunen 2008, Shin et al. 2016). To achieve this objective and in the hope of remaining highly competitive in the marketplace, numerous organizations have launched quality improvement efforts (Paltayian et al. 2012). In the literature, a distinction between quality improvement and quality improvement efforts is noted. While quality improvement is an outcome often based on customers' perceptions of that outcome (Parasuraman et al. 1988), quality improvement efforts are considered an ensemble of activities made by the organisation and is related to quality management processes (Jha et al. 1996). In this study, we focus on the latter concept in the context of services.

${ }^{*}$ Professor of Production and Operations Management, Faculty of Business Administration, University of Moncton, Canada.

${ }^{ \pm}$Professor of Marketing, Faculty of Business Administration, University of Moncton, Canada. 
A review of the literature reveals that most of the research has focused on quality improvement, but very little on quality improvement efforts. Most studies on quality improvement have examined both its causes and consequences. This stream of research was conducted from an internal perspective; their scope was thus defined within an organization's boundaries. For example, several scholars have looked into the factors supporting quality improvement, such as working methods (Maiga and Jacobs 2006, Wright 2013), technologies (Hareton et al. 2007) and organizational learning (Savolainen and Haikonen 2007). Meanwhile, other authors have examined the impact of quality improvement on organizational performance and operational efficiency (Xiaosong et al. 2011) or financial performance (Chatzoglou et al. 2015, Heavey et al. 2014). Concerning quality improvement efforts, it is likely that it can influence the organiszation's external environment, in particular customers' attitudes and behaviours, such as customer satisfaction (Nabavi et al. 2014, Shin et al. 2016) and customer loyalty (Prentice 2013, Santouridis and Trivellas 2010).

In the context of service organizations, service employees and servicescape are considered as two crucial elements that determine the success of the service production and delivery system (Berry 2000, Bitner 1992). Moeller (2010: 363) argues that because of the intangible nature of the service offering "the customer is affected by the tranformation process in general and also by its intangility". Given this intangility, in our view, the customer is confronted with the absence of quantifiable and measurable attibutes in their evaluation process and will tend to use tangible elements associated with the transformation process, namely service employees and servicescape (Zeithaml et al. 2013). In previous studies, the individual and interactive effects of service employees and servicescape on customers' perception of quality improvement efforts have not been extensively addressed (Nilsson and Ballantyne 2014).

Due to strong competition in the higher education sector, universities and colleges alike often establish their positioning strategy based, among other things, on the distinctiveness of faculty members (service employees) and their physical facilities (servicescape). These elements help to demonstrate their ability to fulfill their mission, to retain current students and in the recruitment of new candidates. This strategy based on the organization's distinctiveness in the marketplace is a well-known practice (Busse and Wallenburg 2011, den Hertog et al. 2010). In this study, in a higher education service setting, we investigate the contribution of servicescape in enhancing the effect of service employees on students' perception of quality improvement efforts. Since service employees and servicescape form an integral part of the service encounter, they should act upon the customer's perception in a complementary manner (Lovelock and Wirtz 2011, Zeithaml et al. 2013) and, from our perspective, lead to perceptions of quality and excellence. To that end, Khan and Matlay (2009: 771), in a higher educational setting, propose that "to deliver excellent services to customers requires focused and effective organisational and institutional processes".

To our knowledge, the exact nature of the interdependence between service employees and servicescape is still unspecified in the literature. Nonetheless, there is an evolving stream of research that recognizes the significant role of service employees and the tangible nature of the service engagement platform in the co- 
creation of value (Leclercq et al. 2016, Prahalad and Ramaswamy 2004). Similarly, the foundational premises of the service dominant logic recognizes the importance of employee skills and knowledge, the customer's participation in the service production process, as well as the interactional elements that produce a service in the co-creation of value (Vargo and Lusch 2008, Lusch and Vargo 2014).

In adhering to the service dominant logic of marketing, this study aims to contribute to a better understanding of the impact of service employees and servicescape on customers's perception of quality improvement efforts, as well as their interactive effects. From a managerial perspective, it aims to assist in the formulation of policies and strategies through the judicious use of human resources and physical environment during the service encounter. To that end, the study consists of four parts. Firstly, an overview of the nature of quality improvement efforts is provided, followed by service employees and servicescape. Secondly, the investigation methods are explained. Thirdly, the results are presented and discussed. Finally, the managerial implications concerning the reinforcement of customers' perception of service quality improvement efforts are discussed.

\section{Literature Review}

\section{Service Quality Improvement Efforts}

The concept of service quality has been the concern of numerous studies during the last several decades, from its conceptualization (Grönroos 1984, Parasuraman et al. 1985), its measurement (Bolton and Drew 1991, Cronin and Taylor 1992, Parasuraman et al. 1988), along with its antecedents and consequences (Anderson et al. 1994, Ganguli and Roy 2011, Giovanis et al. 2015, Martin 2016, Prentice 2013, Rauyruen and Miller 2007, Rust et al. 1995). Several definitions of service quality are found in the service management and marketing literature. Service quality is defined as "a perceived judgment, resulting from an evaluation process where customers compare their expectations with the service they perceive to have received" (Grönroos 1984: 38) or as "the degree of discrepancy between customers' normative expectations of the service and their perceptions of the service performance" (Parasuraman et al. 1988: 17) or as the consumer's overall impression with regard to its superiority (Bitner and Hubbert 1994). Overall, service quality is seen as a gap between expectations and outcomes.

A review of the literature reveals that several authors have examined the individual influence of service employees (Dean and Rainnie 2009, Wu et al. 2015) servicescape (Reimer and Kueln 2005, Rosenbaum and Massiah 2011) on customers' perception of quality. Nevertheless, there is very little empirical evidence on the impact of service employees, servicescape and their interactive effects on customers' perception of the efforts made by an organization to improve quality. 
Quality improvement efforts is an important aspect of quality management. Some research on quality improvement has focused on the attributes of the product or service (Nilsson-Witell et al. 2005). During total quality management, quality improvement efforts must also be based on other elements, such as the environment, the employees and the process that directly affect the quality of the product or service (Oprime et al. 2012, Slatten 2010).

Within a service organization, quality improvement efforts are a formal approach to the analysis of the performance of the service production and delivery system, whose objective is to assist management with key decisions aimed at improving quality. These resulting efforts must be translated into concrete results for the benefit of customers. Due to the intangible nature of a service, its tangible elements play an important role on the efforts made to improve quality (Moeller 2010, Rosenbaum and Massiah 2011, Zeithaml et al. 2013). These elements can be grouped into two components of the service production and delivery system: service employees (Dean and Rainnie 2009, Elmadag et al. 2008, Sharabi 2013), responsible for the delivery of service, and servicescape (Hooper et al. 2013, Kok et al. 2015, Nilsson and Ballantyne 2014), the physical environment where the sevice is performed.

From a relationship marketing perspective, it is therefore crucial for the service organization to send a clear message to the marketplace that quality improvement efforts are made on an ongoing basis, in order to reassure consumers of its desire to meet or exceed their expectations. From this perspective, a better knowledge of the consumer's perception of these efforts plays a pivotal role in quality improvement (Chaplin and O'Rourke 2014).

\section{Service Employees}

A service is the outcome of the interaction between the customer, employee and servicescape (Zeithaml et al. 2013). In the service encounter, "service employees play a predominant role, along with customers, and have to accomplish tasks planned and specified in a script describing the role of each participant during the course of operations" (Nguyen and LeBlanc 2002: 245). The important role of service employees during the service encounter has been acknowledged in the literature (Tombs and Rao Hill 2014). Indeed, the actions of service employees affect greatly customers' perception (Wu et al. 2015). In general, their role is twofold: gathering information and serving customers (Aldrich and Herker 1979). Because of their strategic position, service employees receive different kinds of information from customers, mostly related to the service offering and delivery procedures. These types of information may be helpful to management while they attempt to improve service quality. Therefore, the direct contact employees have with customers as well as their knowledge of the service production and delivery system make them an important source of information for the organization when developing service improvement programs. Moreover, as representatives of the organization they have a marketing role that influences relations with customers. Many service employees are considered part-time marketers, because they "conduct marketing activities but do not belong to the marketing or sales department" (Gummesson 1991: 60). They are trained to meet the customer's 
expectations and to protect the organization's interests, elements that are also key to quality improvement efforts. According to the structure of the service offering, service employees can be divided into two groups: the main staff responsible for providing core service and support staff responsible for providing peripheral services.

The performance of service employees largely depends upon their ability to produce and deliver the service offering that satisfies the customers' needs and expectations (Zeithaml et al. 2013). For example, in a higher education setting, the expertise of faculty, their teaching ability and their willingness to help students in their learning process are key elements that lead to student satisfaction and educational quality. A service organization wishing to undertake quality improvement efforts must focus on enhancing their competence (Delcourt et al. 2013) and benevolence (Lee et al. 2004), two major determinants of trust put into practice during the service encounter, or even their physical appearance (Söderlund and Rosengren 2008, Tombs and Rao Hill 2014). By doing this, the organization seeks to ensure that customers have positive perceptions towards its efforts to improve quality and, ultimately, customer loyalty (Vlachos et al. 2013). Hence, the first hypothesis:

$H_{1}$ : The more positive the customer's perception of service employees, the greater is his/her perception of the organization's efforts to improve service quality.

\section{Servicescape}

The servicescape is the physical environment where a service is produced and consumed (Baker 1987, Bitner 1992). This environment is considered to be the packaging of services, and has three components: ambient conditions, spatial layout, and decor and orientation signals (Bitner 1992). Ambient conditions are the various elements such as colour, light, temperature, noise, odour and music, all of which might have the potential to affect the customers' five senses, which influence their perception as well as their response to the environment. For example, Lee et al. (2018), show that the use of gold-related colour bill folders and tabletops in a restaurant setting has a positive impact on the patron's tipping behaviour. Biswas et al. (2019: 47), for their part, reveal that low volume music/noise leads to an increase of healthy food choices in restaurants due to induced relaxation and that high-volume music/noise increases excitement levels, leading to unhealthy food choices. Spatial layout is the design and arrangement of buildings, equipment, and furniture according to the needs of the service delivery process. Decor and orientation signals are visual symbols used to create an appropriate atmosphere and direct customers during the service encounter. In the context of higher education, the comfort and layout of classrooms and residences, the ambient conditions in the library as well as the equipment and technology used by student are examples of elements of the servicescape. Overall, researchers have underlined its influential role in the service production and delivery system and its potential to affect the customer's behavior towards the organization (Daunt and 
Greer 2015, Rosenbaum and Massiah 2011).

From the customer's perspective, reactions to the servicescape can be categorized according to three levels: cognitive, physiological and emotional (Bitner 1992, Tombs and McColl-Kennedy 2003). At the cognitive level, the customer finds in the servicescape various non-verbal cues, which communicate the nature of the service offering and the value of the service provider's reputation. The physiological reaction, for its part, is a result of the ambient conditions present in the setting. It may cause comfort or discomfort during the service encounter, which encourages the customer to pursue or interrupt service consumption, and consequently may have an influence on his attitudes and behaviours towards the service provider (Donovan and Rossiter 1982). Finally, the servicescape may elicit an emotional reaction that can also affect attitudes and behaviour (Mattila and Wirtz 2001, Mehrabian and Russell 1974).

A service organization wishing to implement quality improvement efforts associated with the servicescape in order to improve quality must therefore focus on the elements that promise to ensure favourable perceptions of customers toward the organization, such as the design, the layout and the technology used during the service encounter (Hooper et al. 2013, Psomas et al. 2011). Therefore, the second hypothesis:

$\mathrm{H}_{2}$ : The more positive the customer's perception of the servicescape, the greater is his/her perception of the organization's efforts to improve service quality.

\section{Interactive Effect of Service Employees-Servicescape on Quality Improvement Efforts}

A service is the result of the social interaction between employees and customers that takes place in a physical setting. Servicescape can influence both the employees' performance (Ali et al. 2015) and customers' attitudes and behaviours (Zeithaml et al. 2013). From an internal perspective of the organization, it is important to understand the nature of the interdependence between service employees and servicescape in order to improve quality.

Previous studies have separately examined the influence of service employees (Dean and Rainnie 2009, Wu et al., 2015) and servicescape (Hooper et al. 2013, Mattila and Wirtz 2001) on customers' perceptions of quality. In this study, these two components of the service production and delivery system are combined in assessing their effect on customers' perception of quality improvement efforts. The foundational premises of the service dominant logic of marketing proposed by Vargo and Lusch (2008) and Lusch and Vargo (2014), recognizes the important role of employee skills and knowledge, the customers participation in the service production process as well as the interactional elements that produce a service output in the co-creation of value. Dollinger et al. (2018: 219), in their work on the co-creation of value in higher education, report that the nature of the quality of the interactions has traditionally investigated the student-faculty relations. The interaction between service employees and servicescape merits investigation since it has the potential to impact on customers' perception of quality improvement 
efforts. In recognizing this interactive effect, it is expected that the ability of employees to improve quality can be enhanced if they work in an environment that is well designed to meet their specific needs during the service encounter. This enhanced ability should have a positive impact on customers' perception of the organization's efforts to improve quality and, in turn, lead to loyalty. Accordingly, the third hypothesis is formulated:

$H_{3}$ : The customer's perception of servicescape will moderate the relationship between his/her perception of service employees and his/her perception of the organization's efforts to improve service quality.

The proposed links between service employees, servicescape and service quality improvement efforts are graphically presented in Figure 1.

Figure 1. Relationship between Service Employees, Servicescape and Perception of Quality Improvement Efforts

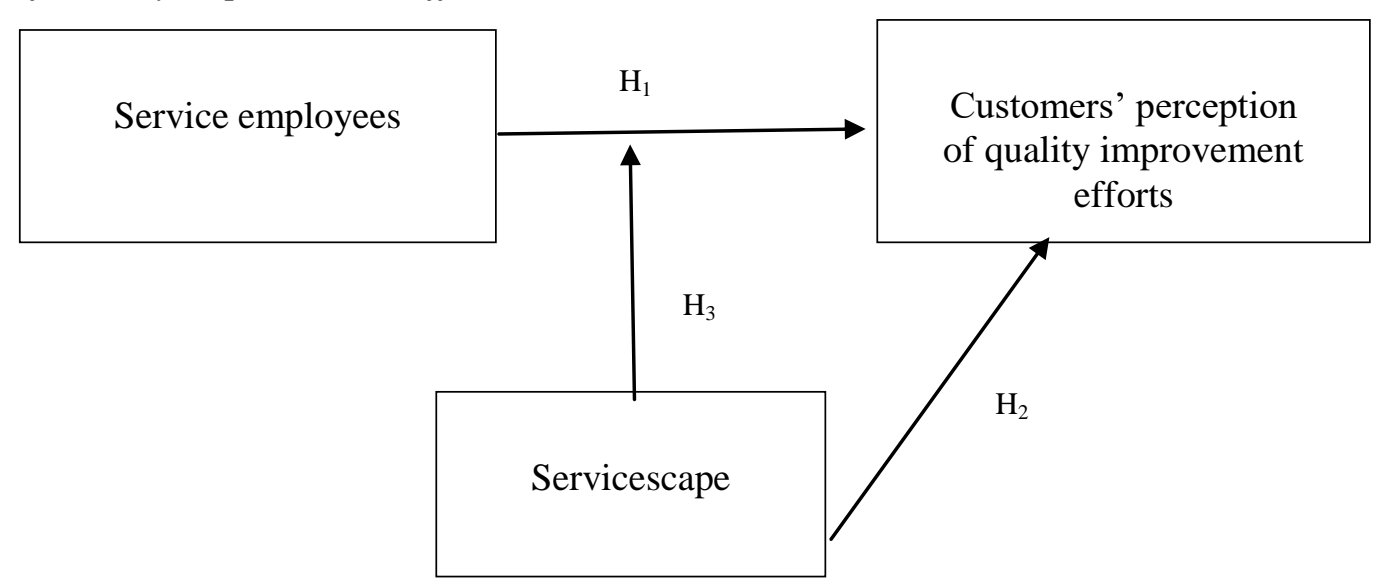

\section{Method}

Sample

Data for this study was collected in a university situated in eastern Canada. As this is an exploratory study, the sample used came from a single university in the region. Convenience sampling was used, based on the list of courses of the 3rd and 4th years of the undergraduate programs, and from the graduate programs of several faculties. Questionnaires were distributed during a two-week period in randomly chosen classes. The questionnaires included an explicative note and contact information. The final sample was composed of 435 respondents, $41 \%$ of which were male and $59 \%$ female, $87 \%$ undergraduate students and $13 \%$ graduate. Overall, 55\% were enrolled in the social sciences and humanities programs while $45 \%$ were in sciences and engineering. In all, $82 \%$ were Canadian students and the other $18 \%$ international students. 


\section{Analysis Procedure}

The assessment of the main influence of service employees and servicescape, and their interactive effect on the customer's perception of quality improvement efforts was conducted following the procedure proposed by Taylor (1997), based on hierarchical multiple regression with interaction. This procedure seeks to detect the presence of potential higher order terms and, if need be, to include them in the regression model. Taylor (1997: 137) has underlined that "failing to capture true higher order and/or interaction effects can lead to problems associated with interpreting regression coefficients, particularly as importance weights." In the context of the current research, the regression model relating two independent variables to a dependent variable takes the form as follows:

\section{IE $=\beta_{0}+\beta_{1} \mathrm{SE}+\beta_{2} \mathrm{SC}+\beta_{3} \mathrm{SE} * \mathrm{SC}+$ POTENTIAL HIGHER ORDER TERMS $+\varepsilon \quad[1]$}

Where:

IE $=$ Customer's perception of quality improvement efforts made by the service organization

$\mathrm{SE}=$ Customer's perception of the performance of service employees of the service organization

$\mathrm{SC}=$ Customer's perception of the servicescape of the service organization

$\mathrm{SE}^{*} \mathrm{SC}=$ Interaction between service employees and servicescape

HIGHER ORDER TERMS: A set of higher order terms up to cubic form as well as other interaction effects.

\section{Measurement}

A review of the literature reveals the existence of various scales developed specifically for certain characteristics of service employees such as competence and trust, but not for service employees as a whole. There are, for example, multiitem scales developed for B2B seller competence (Rosenzweig and Roth 2007), new service development competence (Menor and Roth 2007), enterprise resource planning competence (Stratman and Roth 2002) or network competence (Ritter et al. 2002). Concerning servicescape, a multi-item scale has recently been proposed for the educational sector (Goi and Kalidas 2015). However, this scale is applied to a specific higher education institution and has dimensions unrelated to servicescape as defined in the literature. Nonetheless, two items from this scale, parking and restaurant, were retained in this study. Let us remember that the purpose of this research is not to develop multi-items scales. In this context, to quantify these concepts as presented in equation [1] we used direct measures.

The selection of items to assess service employees and servicescape in the present research was based on the meaning of each construct as recognized in the literature and the dimensions identified by a focus group carried out with students. The focus group was conducted with eight members, four men and four women, ranging in age from 20 to 32 . The discussion, led by a researcher, lasted one hour 
and a half, and covered various issues surrounding educational services provided by the university with a focus on faculty members, other employees and physical facilities. The information generated corresponds largely to the definition of these constructs in the literature. One can observe the similarity between certain dimensions of the service quality measurement scale, SERVQUAL, (Parasuraman et al. 1988). This overlap is explained by the fact that service quality is a concept that incorporates the performance of employees and physical facilities. However, the purpose of this study is to measure perceptions of quality improvement efforts that, in turn, lead to the outcome.

First, five items were used for the measurement of service employees. Three items are for the group of employees having a leading role in the service production and delivery system: expertise of faculty members, their teaching ability and their willingness to supervise students. Two other items for other employees in their supporting role were included: staff responsiveness and willingness to help students. Second, eight items were chosen to describe various components of servicescape: comfort and layout of classrooms, equipment and technology used in classrooms, equipment and technology used in other services, comfort and layout in library, sports facilities, student residences, cafeteria and other food services, and parking space.

Finally, six items were used to describe the efforts made by the organization to improve quality: institution making efforts to offer better study programs, institution-taking actions to improve service quality, management being well informed about novelty in higher education, management promoting continuous renewal, work philosophy based on continuous renewal and management encouraging employees to adopt continuous renewal. Appendix I shows the 19 items used in this study.

Since the constructs examined in the present study are multidimensional, the advantage of these measures lies in the use of indexes formed from multiple indicators that are summed and averaged rather than a single-item measure (Taylor and Baker 1994). All the measures are presented in a statement on a bipolar sevenpoint agreement responses with anchors of strongly disagree (1) and strongly agree (7). The correlation matrix of these items, presented in Table 1, shows that Spearman's correlation coefficients between the measures within a specific concept (varying from 0.214 to 0.764 ) are generally greater than those between the measures from different concepts (varying from 0.107 to 0.467 ). In addition, Table 2 shows adequate values of Spearman's item-index correlation (between 0.485 and 0.886). The assessment of the discriminant validity of the two indexes SE (for service employees) and SC (for servicescape) used as independent variables in equation [1] was performed according to the procedure proposed by Fornell and Larcker (1981) by comparing the values of average variance extracted (AVE) of each index to their squared correlation coefficient. To do this, a confirmatory factor analysis (CFA) was performed on thirteen measures used for the two indexes (five for SE and eight for SC). The CFA loadings are presented in Table 2. With loading coefficients of $0.688,0.651,0.610,0.541$ and 0.503 for SE, and $0.807,0.771,0.701,0.671,0.634,0.615,0.612$ and 0.524 for SC, the AVE values of the indexes ( 0.686 for SE and 0.793 for SC) were both above their squared 
correlation coefficient (0.199). The results of the overall model were considered acceptable in accordance with the model's main statistics, except for the value $\chi^{2} / n$ $=3.88$, which was slightly above the norm (i.e., 3.00), but statistically significant at $\mathrm{p}=0.000$. Indicators, such as the "Normed Fit Index" (NFI $=0.930$ ), the "Incremental Fit Index" (IFI = 0.920), and the "Comparative Fit Index" (CFI= 0.923), were also acceptable. Furthermore, the value of the indicator "root mean square error of approximation" (RMSEA) was equal to 0.078, which is below the limit of acceptability of 0.08 (Byrne, 2001). With acceptable Cronbach's alpha values of these indexes (between 0.767 and .919) and considering the exploratory nature of the present study (Nunnally 1978), these results constitute a demonstration, although partial and limited, of the validity and the reliability of the used measures.

\section{Results and Discussion}

Following the procedure suggested by Taylor (1997), the results of identifying the (linear or curvilinear) nature of the relationship between the dependent variable (quality improvement efforts) and two independent variables (service employees and servicescape) are reported in Table 3.

As can be observed, the quadratic term associated only with service employees is statistically significant. In light of these results, the form of equation [1] connecting service employees and servicescape with quality improvement efforts and subject to testing is expressed as follows:

$\mathrm{IE}=\beta_{0}+\beta_{1} \mathrm{SE}+\beta_{2} \mathrm{SC}+\beta_{3} \mathrm{SE} * \mathrm{SC}+\beta_{4} \mathrm{SE}^{2}+\beta_{5} \mathrm{SE}^{2 *} \mathrm{SC}+\varepsilon$

The next step of the analysis procedure consists of estimating various regression models derived from equation [2] and evaluating the change in the coefficient of determination $\left(R^{2}\right)$ in a hierarchical manner conforming to the apparition order of the independent variables as specified. As the independent variables are closely related, the centered data have been used to attenuate the error caused by the potential problem of multicollinearity (Aiken and West 1991, Cronbach 1987). Table 4 presents the results of the hierarchical multiple regression analysis and the variance inflation factor (VIF) values estimated for various models. 
Table 1. Correlation Matrix of the Items Used in the Model

\begin{tabular}{|c|c|c|c|c|c|c|c|c|c|c|c|c|c|c|c|c|c|c|c|}
\hline Variables & SE1 & SE2 & SE3 & SE4 & SE5 & $\mathrm{SC} 1$ & $\mathrm{SC} 2$ & $\mathrm{SC} 3$ & SC4 & SC5 & SC6 & SC7 & SC8 & IE1 & IE2 & IE3 & IE4 & IE5 & IE6 \\
\hline SE2 & 0.628 & & & & & & & & & & & & & & & & & & \\
\hline SE3 & 0.497 & 0.463 & & & & & & & & & & & & & & & & & \\
\hline SE4 & 0.487 & 0.403 & 0.501 & & & & & & & & & & & & & & & & \\
\hline SE5 & 0.409 & 0.405 & 0.409 & 0.483 & & & & & & & & & & & & & & & \\
\hline $\mathrm{SC} 1$ & 0.296 & 0.312 & 0.322 & 0.375 & 0.324 & & & & & & & & & & & & & & \\
\hline $\mathrm{SC} 2$ & 0.261 & 0.242 & 0.351 & 0.386 & 0.314 & 0.612 & & & & & & & & & & & & & \\
\hline $\mathrm{SC} 3$ & 0.210 & 0.254 & 0.284 & 0.347 & 0.315 & 0.497 & 0.471 & & & & & & & & & & & & \\
\hline $\mathrm{SC} 4$ & 0.203 & 0.118 & 0.272 & 0.385 & 0.267 & 0.436 & 0.504 & 0.430 & & & & & & & & & & & \\
\hline SC5 & 0.260 & 0.149 & 0.318 & 0.367 & 0.194 & 0.416 & 0.490 & 0.352 & 0.465 & & & & & & & & & & \\
\hline SC6 & 0.231 & 0.226 & 0.199 & 0.168 & 0.226 & 0.458 & 0.440 & 0.375 & 0.374 & 0.378 & & & & & & & & & \\
\hline $\mathrm{SC} 7$ & 0.193 & 0.272 & 0.250 & 0.189 & 0.179 & 0.422 & 0.380 & 0.347 & 0.361 & 0.317 & 0.395 & & & & & & & & \\
\hline $\mathrm{SC} 8$ & 0.107 & 0.181 & 0.145 & 0.125 & 0.197 & 0.316 & 0.373 & 0.419 & 0.214 & 0.351 & 0.376 & 0.424 & & & & & & & \\
\hline IE1 & 0.465 & 0.445 & 0.467 & 0.440 & 0.361 & 0.327 & 0.225 & 0.396 & 0.300 & 0.271 & 0.305 & 0.351 & 0.258 & & & & & & \\
\hline IE2 & 0.397 & 0.464 & 0.449 & 0.418 & 0.391 & 0.382 & 0.342 & 0.389 & 0.217 & 0.269 & 0.378 & 0.435 & 0.287 & 0.744 & & & & & \\
\hline IE3 & 0.312 & 0.436 & 0.431 & 0.366 & 0.365 & 0.287 & 0.269 & 0.323 & 0.140 & 0.225 & 0.334 & 0.411 & 0.304 & 0.600 & 0.705 & & & & \\
\hline IE4 & 0.304 & 0.336 & 0.352 & 0.406 & 0.414 & 0.315 & 0.294 & 0.327 & 0.221 & 0.219 & 0.295 & 0.356 & 0.244 & 0.561 & 0.606 & 0.743 & & & \\
\hline IE5 & 0.386 & 0.452 & 0.410 & 0.412 & 0.392 & 0.319 & 0.318 & 0.400 & 0.181 & 0.231 & 0.266 & 0.427 & 0.276 & 0.608 & 0.685 & 0.764 & 0.739 & & \\
\hline IE6 & 0.400 & 0.463 & 0.465 & 0.338 & 0.336 & 0.275 & 0.247 & 0.281 & 0.173 & 0.204 & 0.288 & 0.452 & 0.250 & 0.490 & 0.582 & 0.645 & 0.625 & 0.733 & \\
\hline MEAN & 5.15 & 4.42 & 5.09 & 5.15 & 4.71 & 4.83 & 5.27 & 5.00 & 5.63 & 5.25 & 4.49 & 3.86 & 2.73 & 4.88 & 4.40 & 4.42 & 4.62 & 4.42 & 4.52 \\
\hline S.D. & 1.34 & 1.53 & 1.20 & 1.24 & 1.57 & 1.47 & 1.35 & 1.71 & 1.31 & 1.34 & 1.30 & 1.70 & 1.81 & 1.28 & 1.37 & 1.38 & 1.20 & 1.27 & 1.36 \\
\hline
\end{tabular}


Table 2. Coefficients of Spearman Correlation Inter Index-Item, CFA Loadings and Cronbach's Alpha Coefficients

\begin{tabular}{|c|c|c|c|c|}
\hline $\begin{array}{l}\text { Indices } \\
\text { (Construct) }\end{array}$ & $\begin{array}{l}\text { Speat } \\
\text { corre }\end{array}$ & & $\begin{array}{l}\text { CFA } \\
\text { loadings }\end{array}$ & $\begin{array}{l}\text { Cronbach's } \\
\text { alpha }\end{array}$ \\
\hline $\begin{array}{l}\text { SE } \\
\text { (Service employees) }\end{array}$ & $\begin{array}{l}\text { SE1 (Expertise of faculty members) } \\
\text { SE2 (Ability of teaching of faculty members) } \\
\text { SE3 (Student supervision by faculty members) } 0.728 \\
\text { SE4 (Staff responsiveness) } \\
\text { SE5 (Staff willing to help) }\end{array}$ & $\begin{array}{l}0.734 \\
0.745 \\
0.610 \\
0.685 \\
0.682\end{array}$ & $\begin{array}{l}0.688 \\
0.651 \\
0.541 \\
0.503\end{array}$ & 0.774 \\
\hline $\begin{array}{l}\mathrm{SC} \\
\text { (Servicescape) }\end{array}$ & $\begin{array}{l}\text { SC1 (Comfort and layout of classrooms) } \\
\text { SC2 (Equipment and technology } \\
\quad \text { used in classrooms) } \\
\text { SC3 (Equipment and technology used in other services) } \\
\text { SC4 (Comfort and layout in library) } \\
\text { SC5 (Sports facilities) } \\
\text { SC6 (Student residences) } \\
\text { SC7 (Cafeteria and other food services) } \\
\text { SC8 (Parking space) }\end{array}$ & $\begin{array}{l}0.728 \\
0.667 \\
0.605 \\
0.571 \\
0.603 \\
0.592 \\
0.485\end{array}$ & $\begin{array}{l}0.807 \\
0.771 \\
0.701 \\
0.671 \\
0.634 \\
0.615 \\
0.612 \\
0.524\end{array}$ & 0.767 \\
\hline $\begin{array}{r}\text { IE (Quality improvement } \\
\text { efforts) }\end{array}$ & $\begin{array}{l}\text { IE1 (Institution making efforts to offer (Quality) } \\
\text { better study programs) } \\
\text { IE2 (Institution taking actions to improve } \\
\quad \text { service quality) } \\
\text { IE3 (Management being well-informed } \\
\text { about novelty in higher education) } \\
\text { IE4 (Management promoting continuous renewal) } \\
\text { IE5 (Work philosophy based on continuous renewal) } \\
\text { IE6 (Management encouraging employees } \\
\text { to adopt continuous renewal) }\end{array}$ & $\begin{array}{l}0.870 \\
0.821 \\
0.886\end{array}$ & $\begin{array}{l}0.818 \\
0.775 \\
0.845 \\
0.749\end{array}$ & 0.919 \\
\hline
\end{tabular}


Table 3. Identification of the Nature of the Relationship between the Perception of Quality Improvement Efforts and each Independent Variable

\begin{tabular}{lllll}
\hline Model & $\mathrm{R}^{2}$ & $\mathrm{p}$ & & \\
\hline & & & & \\
$\mathrm{IE}=0.647 \mathrm{SE}$ & 0.418 & 0.000 & $\mathrm{~F}(1,431)=309.93$ & \\
$\mathrm{IE}=0.667 \mathrm{SE}+0.074 \mathrm{SE}^{2}$ & 0.423 & 0.000 & $\mathrm{~F}(2,430)=157.82$ & Significant quadratic term $(\mathrm{p}=0.050)$ \\
$\mathrm{IE}=0.636 \mathrm{SE}+0.091 \mathrm{SE}^{2}+0.047 \mathrm{SE}^{3}$ & 0.424 & 0.000 & $\mathrm{~F}(3,429)=105.24$ & $\begin{array}{l}\text { Significant quadratic term }(\mathrm{p}=0.048) \\
\end{array}$ \\
& & & & No significant cubic term $(\mathrm{p}=0.491)$ \\
$\mathrm{IE}=0.578 \mathrm{SC}$ & 0.334 & 0.000 & $\mathrm{~F}(1,431)=213.52$ & \\
$\mathrm{IE}=0.582 \mathrm{SC}+0.044 \mathrm{SC}^{2}$ & 0.336 & 0.000 & $\mathrm{~F}(2,430)=107.43$ & No significant quadratic term $(\mathrm{p}=0.269)$ \\
$\mathrm{IE}=0.482 \mathrm{SC}+0.063 \mathrm{SC}^{2}+0.123 \mathrm{SC}^{3}$ & 0.340 & 0.000 & $\mathrm{~F}(3,429)=72.88$ & No significant quadratic $(\mathrm{p}=0.125)$ \\
& & & & and no significant cubic terms $(\mathrm{p}=0.092)$
\end{tabular}


Table 4. Estimates of Various Regression Models from Equation [2]

\begin{tabular}{|c|c|c|c|c|c|c|}
\hline \multicolumn{2}{|c|}{$\begin{array}{l}\text { Estimated } \\
\text { Model }\end{array}$} & \multirow{2}{*}{$\begin{array}{r}\text { Variable Beta } \\
0.476\end{array}$} & \multirow{2}{*}{$\begin{array}{l}\mathrm{t} \text {-value } \\
11.632\end{array}$} & \multirow{2}{*}{$\frac{p \text {-value }}{0.000}$} & \multirow{2}{*}{$\begin{array}{c}\mathrm{R}^{2} \quad \mathrm{VIF} \\
0.496\end{array}$} & \multirow{2}{*}{$\frac{\text { Tolerance }}{1.40}$} \\
\hline 1 & SE & & & & & \\
\hline 0.71 & $\mathrm{SC}$ & 0.322 & 7.872 & 0.000 & & 1.40 \\
\hline \multirow[t]{3}{*}{$\begin{array}{l}2 \\
0.70\end{array}$} & SE & 0.490 & 11.997 & 0.000 & $0.506^{\mathrm{a}}$ & 1.42 \\
\hline & $\begin{array}{l}\text { SC } \\
0.71\end{array}$ & 0.329 & 7.845 & 0.000 & & 1.41 \\
\hline & $\begin{array}{l}\text { SE*SC } \\
0.98\end{array}$ & 0.101 & 2.930 & 0.004 & & 1.01 \\
\hline 3 & SE & 0.472 & 10.350 & 0.000 & $0.507^{\mathrm{b}}$ & 1.77 \\
\hline 051 & $\mathrm{SC}$ & 0.296 & 6.169 & 0.000 & & 1.95 \\
\hline & $\mathrm{SE} * \mathrm{SC}$ & 0.119 & 2.966 & 0.007 & & 1.65 \\
\hline 0.01 & $\mathrm{SE}^{2}$ & -0.012 & -0.286 & 0.775 & & 1.58 \\
\hline 0.42 & $\mathrm{SE}^{2} * \mathrm{SC}$ & 0.049 & 0.924 & 0.356 & & 2.39 \\
\hline
\end{tabular}

${ }^{\mathrm{a}} \Delta \mathrm{R}^{2}=0.01, \mathrm{~F}_{1,431}=8.68, \mathrm{p}=0.0034$

${ }^{\mathrm{b}} \Delta \mathrm{R}^{2}$ is not significant

These results reveal that the regression coefficients representing the main effect of service employees and servicescape on customer's perception of quality improvement efforts is statistically significant in the presence of the interaction term between service employees and servicescape ( $\mathrm{SE} * \mathrm{SC}$ ). These results confirm the hypotheses $\mathrm{H}_{1}$ and $\mathrm{H}_{2}$. The effect of service employees on the perception of quality improvement efforts is more important than servicescape (beta of $\mathrm{SE}=$ 0.490 compared to beta of $S C=0.329$ in model 2 in Table 4). This result suggests, therefore, the crucial role of employees in the process of improving service quality in higher education as mentioned in the literature (Sharabi 2013).

Regarding the coefficient associated with the term SE*SC, it is statistically significant and confirms the hypothesis $H_{3}$, but with small magnitude (beta of $\mathrm{SE}^{*} \mathrm{SC}=0.101$ in model 2 and beta of $\mathrm{SE}^{*} \mathrm{SC}=0.119$ in model 3 in Table 4). Because of the small magnitude and the exploratory nature of the study, this result should be interpreted with caution. Despite this remark, the significance of the interaction term found here is worth noting given the difficulty to detect statistically reliable interactions as suggested by numerous researchers in the field (Taylor and Baker, 1994). Consequently, we note that the presence of the interaction between service employees and servicescape contributes to a better explanation of the customer's perception of quality improvement efforts. Moreover, the results show that the effect of service employees increases when 
servicescape is stronger (beta of $\mathrm{SE}=0.476$ comparing to beta of $\mathrm{SE}=0.490$ when beta of SC increases from 0.322 to 0.329 in the presence of SE*SC in models 1 and 2 in Table 4). Consequently, these results suggest the moderator role of servicescape in the relationship between service employees and quality improvement efforts. Since the coefficient of the term SE*SC is positive, this result can be interpreted as a congruence between perceptions of service employees and servicescape. Statistically, the positive value of the coefficient associated with the term $\mathrm{SE}^{*} \mathrm{SC}$ indicates that the interactive effect increases (decreases) when the perception of servicescape increases (decreases). This result demonstrates that service workers and servicescape are an integral part of the service production and delivery system (Zeithaml et al. 2013), and they must be jointly designed, developed and managed in quality improvement programs that are linked with organizational values and strategy (Jha et al. 1996). In the context of higher educational institutions, the inseparability between service employees and servicescape seems even more obvious because of the need to provide an environment conducive to exchanges between faculty members and students or learning itself.

Concerning superior order terms, the results in Table 4 show that their coefficients are not statistically significant. Therefore, these results allow us to conclude that the model without higher order terms is appropriate. The results presented in Table 4 also reveal that the change in the coefficient of determination $\left(\Delta R^{2}\right)$ is statistically significant in the presence of the interaction term $\left(\Delta R^{2}\right.$ is significant from model 1 to model 2 in Table 4).

\section{Conclusion}

Considering the results obtained in this study, a service organization should put its focus on service employees and servicescape in order to ensure favourable perception of customers towards the organization's efforts to improve quality.

Regarding service employees, the continuous improvement of their performance should be a guideline in human resources management and several actions could be considered, such as strengthening their competence and encouraging their benevolence towards customers during the service encounter. To strengthen the competence of service employees, first, management must develop an environment that facilitates individual learning (Oprime et al. 2012) with the purpose of encouraging the acquisition and sharing of information and knowledge related to the service production and delivery system. From this perspective, a training program against industry best-practice standards must support the upgrading of specific knowledge held by each service employee periodically in order to enhance the customer's perception of the service organization's efforts to improve quality.

In the context of higher education, it is imperative to invest in faculty members to develop and deliver high quality curriculum. For example, to maximize their contribution, the institution should provide them with the means to renew continuously their skills to ensure a creative and effective teaching for 
students to acquire new knowledge to solve new problems (Sharabi 2013). The institution should establish a permanent structure for the development of skills to maintain or increase its capital of competence (Bouteiller 2009). On the one hand, this structure could focus on formal training practices for improving teaching skills or those associated with the optimal use of information technology and communication. On the other hand, this structure can also be directed towards informal training activities that promote meetings and discussion among faculty where the more experienced faculty would be asked to provide some guidance to new hires (Kelleher et al 2019). In the case of a higher education institution, promoting benevolent behaviour among faculty members and other employees for the well-being of students means that the university or college is taking action to ensure the success of the learning process. This in turn helps to reinforce the perception among students that the institution is making efforts to provide better educational services.

Concerning servicescape, because of its strong influence on the performance of service employees, it must be designed in response to two types of needs: operations needs, expressed by the maximisation of organizational efficiency, and marketing needs, to create an environment that influences customers' attitudes and beliefs toward the service organization (Hooper et al. 2013). In reference to operations needs, the spatial layout of the environment must aid in the accomplishment of both the employee's and the customer's tasks during the service encounter. In a higher education setting, its improvement must be guided by a judicious choice of various elements such as comfort and layout of classrooms and library, equipment and technology used in classrooms and other services in order to provide better educational services. Indeed, in this context, the servicescape has the potential to influence students' expectations and perceptions of the value proposition of their institution (Nilsson and Ballantyne 2014). From our perspective, it also promises to contribute to the creation of a unique distinctiveness in the positioning strategy of higher education institutions that are faced with strong competition.

Regarding the interactive effect of service employees and servicescape on perceptions of quality improvement efforts, in our view, this interactive process is key to the transformation process and delivery of quality educational services. Therefore, the educational institution must build up its quality improvement program based on the continuous renewal of knowledge aimed at strengthening the competence of faculty and a servicescape designed to maximize organizational efficiency and distinctiveness. The focus on these key elements promises to lead to favorable perceptions of the efforts made by the institution to continuously improve the quality of its offer.

\section{Limitations and Further Research}

The limits of the present study should not be ignored. Firstly, the exploratory nature of this study does not allow for the generalization of the findings to all types of service settings because of the great variety in service industries, especially since the data were collected from a convenient sample. Secondly, the efficacy of 
the direct measures used in the evaluation of service employees, servicescape and quality improvement efforts must be considered (Peterson and Wilson 1992). The selection of these measures was based on the meaning of each of the three constructs, in the absence of measurement scales. Thirdly, the hierarchical multiple regression with interaction method used here is not necessarily superior to other techniques to investigate potential higher-order and/or interactive effects (Jaccard et al. 1990, Taylor 1997). For example, structural equation modelling with latent variables is a prominent alternative technique. However, this method, more complex, is not able to examine the subtle distinction between closely linked constructs (Iacobucci et al. 1994). Finally, the weak variation of the coefficient of determination between estimated model 1 and 2 in Table 4 should invite us to interpret the results with caution. Concerning future research, it would be helpful to realize similar studies in other service settings. Furthermore, it would be interesting to proceed with other studies to determine the exact nature of the interaction between service employees and servicescape. The work being presently done on the co-creation of value could be the starting point that leads to a better understanding of the interactive process in a «collective consumption context», (Kelleher et al. 2019).

\section{References}

Aiken LS, West SG (1991) Multiple regression: testing and interpreting interactions. Newbury Park, CA: Sage Publications.

Aldrich HE, Herker D (1979) Boundary-spanning roles and organisational structure. Academy of Management Review 2(2): 217-230.

Ali AS, Chua SJL, Lim MEL (2015) The effect of physical environment comfort on employees performance in office buildings: a case study of three public universities in Malaysia. Structural Survey 33(4/5): 294-308.

Anderson EW, Fornell C, Lehmann DR (1994) Customer satisfaction, market share, and profitability: findings from Sweden. Journal of Marketing 58(3): 53-66.

Baker J (1987) The role of the environment in marketing services: the consumer perspective. In JA Czepiel, CA Congram, J Shanahan (Eds), 79-84. The Service Challenge: Integrating for Competitive Advantage. Chicago: American Marketing Association.

Berry LL (2000) Cultivating service brand equity. Journal of the Academy of Marketing Science 28(1): 128-137.

Biswas D, Lund K, Szocs C (2019) Sounds like a healthy retail atmospheric strategy: effects of ambient music and background noise on food sales. Journal of the Academy of Marketing Science 47(1): 37-55.

Bitner MJ (1992) Servicescapes: the impact of physical surroundings on customers and employees. Journal of Marketing 56(2): 57-71.

Bitner MJ, Hubbert AR (1994) Encounter satisfaction versus overall satisfaction versus quality: the customer's voice. In Rust R, Oliver R (Eds), 72-94. Service Quality: New Directions in Theory and Practice. Thousand Oaks, CA: Sage Publications.

Bolton RN, Drew JH (1991) A multistage model of customers' assessments of service quality and value. Journal of Consumer Research 17(4): 375-384. 
Bouteiller D (2009) Développer les compétences. (Developing skills). In A Bourhis, D Chênevert (Eds), 281-326. A vos Marques, Prêts, Gérez! La GRH pour Gestionnaires. Montreal: ERPI.

Busse C, Wallenburg CM (2011) Innovation management of logistics service provider, foundations, review and research agenda. International Journal of Physical Distribution \& Logistics Management 41(2): 187-218.

Buzzel RD, Weirsema FD (1981) Successful share-building strategies. Harvard Business Review. January/February. 135.

Byrne BM (2001) Structural equation modelling with AMOS, basic concepts, applications and programming. Mahwah, New-Jersey: Lawrence Erlbaum Associates.

Chaplin L, O'Rourke STJ (2014) Lean six sigma and marketing: a missed opportunity. International Journal of Productivity and Performance Management 63(5): 665-674.

Chatzoglou P, Chatzoudes D, Kirpraios N (2015) The impact of ISO 9000 certification on firms' financial performance. International Journal of Operations \& Production Management 35(1): 145-174.

Cronbach LJ (1987) Statistical tests for moderator variables: flaws in analyses recently proposed. Psychological Bulletin 102(3): 414-417.

Cronin JJ, Taylor SA (1992) Measuring service quality: a re-examination and extension. Journal of Marketing 56(3): 55-68.

Daunt KL, Greer DA (2015) Unpacking the perceived opportunity to misbehave: the influence of spatio-temporal and social dimensions on customer misbehaviour. European Journal of Marketing 49(9/10): 1505-1526.

Dean AM, Rainnie A (2009) Frontline employees' views on organizational factors that affect the delivery of service quality in call centers. Journal of Services Marketing 23(5): 326-337.

Delcourt C, Gremler DD, Riel ACR, van Birgelen M (2013) Effects of perceived employee emotional competence on customer satisfaction and loyalty. Journal of Service Management 24(1): 5-24.

den Hertog P, van der Aa W, de Jong MW 2010. Capabilities for managing service innovation: towards a conceptual framework. Journal of Service Management 21(4): 490-514.

Dollinger M, Lodge J, Coates H (2018) Co-creation in higher education: towards a conceptual model. Journal of Marketing for Higher Education 28(2): 210-231.

Donovan RJ, Rossiter JR (1982) Store atmosphere: an environmental psychology approach. Journal of Retailing 58(1): 35-57.

Elmadag AB, Ellinger AE, Franke GR (2008) Antecedents and consequences of frontline service employee commitment to service quality. Journal of Marketing Theory and Practice 16(2): 95-110.

Fornell C, Larcker DF (1981) Evaluating structural equation models with unobservable variables and measurement error. Journal of Marketing Research 18(1): 39-50.

Ganguli S, Roy SK (2011) Generic technology-based service quality dimensions in banking: impact on customer satisfaction and loyalty. The International Journal of Bank Marketing 29(2): 168-189.

Giovanis A, Athanasopoulou P, Tsoukatos E (2015) The role of service fairness in the service quality - relationship quality - customer loyalty chain: an empirical study. Journal of Service Theory and Practice 25(6): 744-776.

Goi MT, Kalidas V (2015) Constructing a servicescape scale for higher education institutions. International Journal of Innovation, Management and Technology 6(3): 191-195.

Grönroos C (1984) A service quality model and its marketing implications. European Journal of Marketing 18(4): 36-44. 
Gummesson E (1991) Marketing-orientation revisited: the crucial role of the part-time marketers. European Journal of Marketing 25(2): 60-75.

Hareton KN, Leung LL, Qu Y (2007) Automated support of software quality improvement. The International Journal of Quality \& Reliability Management 24(3): 230-243.

Heavey C, Ledwith A, Murphy E (2014) Introducing a new continuous improvement framework for increased organizational return on investment. TQM Journal 26(6): 594-609.

Hooper D, Coughlan J, Mullen MR (2013) The servicescape as an antecedent to service quality and behavioural intentions. Journal of Services Marketing 27(4): 271-280.

Iacobucci D, Grayson KA, Ostrom A (1994) The calculus of service quality and customer satisfaction: theoretical and empirical differentiation and integration. In TA Swartz, DE Bowen, SW Brown (Eds), 1-67. Advances in Services Marketing and Management. Greenwich, CT: JAI Press.

Jaccard J, Turrisi R, Wan CK (1990) Interaction effects in multiple regression. Newbury Park, CA: Sage Publications.

Jha S, Noori H, Michela JL (1996) The dynamics of continuous improvement, aligning organizational attributes and activities for quality and productivity. International Journal of Quality Science 1(1): 19-47.

Jiju A (2015) The ten commandments of quality: a performance perspective. International Journal of Productivity and Performance Management 64(5): 723-735.

Kelleher CN, Wilson H, Macdonald EK, Peppard J (2019) The Score is not the music: integrating experience and practice perspectives on value co-creation in collective consumption contexts. Journal of Service Research 22(2): 120-138.

Kettunen J (2008) A conceptual framework to help evaluate the quality of institutional performance. Quality Assurance in Education 16(4): 322-332.

Khan H, Matlay H (2009) Implementing service excellence in higher education. Education and Training 51(8-9): 769-780.

Kok H, Mobach M, Omta O (2015) Facility design consequences of different employees' quality perceptions. The Service Industries Journal 35(3): 152-178.

Leclercq T, Hammedi W, Poncin I (2016) Dix ans de co-creation de valeur: une revue integrative. (Ten years of value co-creation: an integrative review). Recherche et Applications en Marketing 31(3): 29-66.

Lee DJ, Sirgy MJ, Brown JR, Bird MM (2004) Importers' benevolence toward their foreign export suppliers. Journal of the Academy of Marketing Science 32(1): 32-48.

Lee NY, Noble SM, Biswas D (2018) Hey big spender! A golden (color) atmospheric effect on tipping behavior. Journal of the Academy of Marketing Science 46(2): 317337.

Lovelock C, Wirtz J (2011) Services Marketing, People, Technology, Strategy. $7^{\text {th }}$ Edition. Essex: Pearson.

Lusch RF, Vargo SL (2014) Service dominant logic: premises, perspectives, possibilities. Cambridge: Cambridge University Press.

Maiga AS, Jacobs FA (2006) Assessing the impact of benchmarking antecedents on quality improvement and its financial consequences. Journal of Management Accounting Research 18(1): 97-123.

Martin MJ (2016) Customers' determination of service quality and satisfaction in a return/repair process: a quantitative study. International Academy of Marketing Studies Journal 20(1): 36-52.

Mattila AS, Wirtz J (2001) Congruency of scent and music as a driver of in-store evaluation and behaviour. Journal of Retailing 77(2): 273-289.

Mehrabian A, Russell JA (1974) An approach to environmental psychology. Cambridge, 
MA: Massachusetts Institute of Technology.

Menor LJ, Roth AV (2007) New service development competence in retail banking: construct development and measurement validation. Journal of Operations Management 25(4): 825-846.

Moeller S (2010) Characteristics of services - A new approach uncovers their value. Journal of Services Marketing 24(5): 359-368.

Nabavi V, Azizi M, Faezipour M (2014) Implementation of quality management system based on ISO9001: 2008 and its effects on customer satisfaction case study: kitchen worktops factory. The International Journal of Quality \& Reliability Management 31(8): 921-937.

Nguyen N, LeBlanc G (2002) Contact personnel, physical environment and the perceived corporate image of intangible services by new clients. International Journal of Service Industry Management 13(3-4): 242-262.

Nilsson E, Ballantyne D (2014) Reexamining the place of servicescape in marketing: a service-dominant logic perspective. Journal of Services Marketing 28(5): 374-379.

Nilsson-Witell L, Antoni M, Dahlgaard JJ (2005) Continuous improvement in product development, improvement programs and quality principles. International Journal of Quality \& Reliability Management 22(8): 753-768.

Nunnally J (1978) Psychometric theory. New York: McGraw-Hill.

Oprime PC, de Sousa Mendes GH, Pimenta ML (2012) Continuous improvement critical factors in Brazilian industrial companies. International Journal of Productivity and Performance Management 61(1): 69-92.

Paltayian GN, Georgiou AC, Gotzamani KD, Andronikidis AI (2012) An integrated framework to improve quality and competitive positioning within the financial services context. The International Journal of Bank Marketing 30(7): 527-547.

Parasuraman A, Zeithaml VA, Berry LL (1985) A conceptual model of service quality and its implication for future research. Journal of Marketing 49(4): 41-50.

Parasuraman A, Zeithaml VA, Berry LL (1988) SERVQUAL: a multi-item scale for measuring consumer perceptions of service quality. Journal of Retailing 64(1): 1240.

Peterson RA, Wilson RW (1992) Measuring customer satisfaction: fact and artifact. Journal of the Academy of Marketing Science 20(1): 61-71.

Prahalad CK, Ramaswamy V (2004) Co-creation experiences: the next practice in value creation. Journal of Interactive Marketing 18(3): 5-14.

Prentice C (2013) Service quality perceptions and customer loyalty in casinos. International Journal of Contemporary Hospitality Management 25(1): 49-64.

Psomas EL, Fotopoulos CV, Kafetzopoulos DP (2011) Core process management practices, quality tools and quality improvement in ISO9001 certifed manufacturing companies. Business Process Management Journal 17(3): 437-460.

Rauyruen P, Miller K (2007) Relationship quality as a predictor of B2B customer loyalty. Journal of Business Research 60(1): 21-31.

Reimer A, Kuehn R (2005) The impact of servicescape on quality perception. European Journal of Marketing 39(7/8): 785-808.

Ritter T, Wilkinson IF, Johnston WJ (2002) Measuring network competence: some international evidence. The Journal of Business \& Industrial Marketing 17(2/3): $119-138$.

Rosenbaum MS, Massiah C (2011) An expanded servicescape perspective. Journal of Service Management 22(4): 471-490.

Rosenzweig ED, Roth AV (2007) B2B seller competence: construct development and measurement using a supply chain strategy lens. Journal of Operations Management 25(6): 1311-1331. 
Rust RT, Zahorik AJ, Keiningham TL (1995) Return on quality (ROQ): making service quality financially accountable. Journal of Marketing 59(2): 58-70.

Santouridis I, Trivellas P (2010) Investigating the impact of service quality and customer satisfaction on customer loyalty in mobile telephony in Greece. The TQM Journal 22(3): 330-343.

Savolainen T, Haikonen A (2007) Dynamics of organizational learning and continuous improvement in six sigma implementation. The TQM Magazine 19(1): 6-17.

Sharabi M (2013) Managing and improving service quality in higher education. International Journal of Quality and Service Sciences 5(3): 309-320.

Shin N, Park S, Lee S (2016) Korean standard quality excellence index for strategic quality planning and improvement. Total Quality Management \& Business Excellence 27(7-8): 735-750.

Slatten T (2010) Do employees' feelings really matter in service-quality management? European Business Review 22(3): 318-338.

Söderlund M, Rosengren S (2008) Revisiting the smiling service worker and customer satisfaction. International Journal of Service Industry Management 19(5): 552-574.

Stratman JK, Roth AV (2002) Enterprise resource planning (ERP) competence constructs: two-stage multi-item scale development and validation. Decision Sciences 33(4): 601-628.

Taylor SA, Baker TL (1994) An assessment of the relationship between service quality and customer satisfaction in the formation of consumers' purchase intentions. Journal of Retailing 72(2): 163-178.

Taylor SA (1997) Assessing regression-based importance weights for quality perceptions and satisfaction judgments in the presence of higher order and/or interaction effects. Journal of Retailing 73(1): 135-159.

Tombs A, McColl-Kennedy JR (2003) Socio-servicescape conceptual model. Marketing Theory 3(4): 447-458.

Tombs A, Rao Hill S (2014) The effect of service employees' accent on customer reactions. European Journal of Marketing 48(11/12): 2051-2070.

Vargo SL, Lusch RF (2008) Service-dominant logis: continuing the evolution. Journal of the Academy of Marketing Science 36(1): 1-10.

Vlachos PA, Krepapa A, Panagopoulos NG (2013) Curvilinear effects of corporate social responsibility and benevolence on loyalty. Corporate Reputation Review 16(4): 248262.

Wright L (2013) Quality improvement and organizational change initiatives: an analysis of the U.S. army's warrior transition unit (WTU). Academy of Strategic Management Journal 12(2): 95-111.

Wu YC, Tsai CS, Hsiung HW, Chen KY (2015) Linkage between frontline employee service competence scale and customer perceptions of service quality. Journal of Services Marketing 29(3): 224-234.

Xiaosong DP, Schroeder RG, Shah R (2011) Competitive priorities, plant improvement and innovation capabilities, and operational performance. International Journal of Operations \& Production Management 31(5): 484-510.

Zeithaml VA, Bitner MJ, Gremler DD (2013) Services marketing. $6^{\text {th }}$ Edition. New York: McGraw-Hill. 


\section{Appendix I}

\section{Measures of Service Employees, Servicescape and Perception of Quality Improvement Efforts}

Service Employees

SE1 Expertise of faculty members

SE2 Teaching ability of faculty members

SE3 Willingness of faculty members to supervise students

SE4 Staff responsiveness

SE5 Willingness of staff to help students

\section{Servicescape}

SC1 Comfort and layout of classrooms

SC2 Equipment and technology used in classrooms

SC3 Equipment and technology used in other services

SC4 Comfort and layout of library

SC5 Equipment and technology used in library

SC6 Comfort and layout of student residence

SC7 Equipment and technology used in student residence

SC8 Availability of parking space

Perception of Quality Improvement Efforts

IE1 Institution making efforts to improve study programs

IE2 Institution taking actions to improve service quality

IE3 Management being well-informed about novelty in higher education

IE4 Management promoting continuous renewal

IE5 Work philosophy focused on continuous renewal

IE6 Management encouraging employees to adopt continuous renewal 